\title{
酵素による硬質生肉の軟化と旨味生成について(その1) On the Formation of the Tasty Substance in and the Tenderization of Tough Meat by Proteolytic Enzymes (Part 1)
}

\author{
（昭 和 37 年 7 月 15 日受 理）
}

\author{
別 所秀子黑沢 祝子 \\ (Hideko Bessho) (Shikuko Kurosawa)
}

\begin{abstract}
In order to improve the tastiness and tenderness of raw beef in the cooking of tough round steak, the effects of various proteolytic enzymes on meat were investigated. In the formation of tastiness and tenderness, the protease of Rhizopus genus mold was found to be best by the organoleptic test, followed by Bacillus subtilis alkaline protease, Bromelain and Ficin in the decreasing order. Every proteolytic enzyme used there showed that it had its own specific amount of enzyme activity to give the best tastiness and tenderness to meat. In the cases of Bromelain and Bacillus subtilis alkaline protease, however, the taste of meat is noticeably affected by the amount of enzyme used, and even a slightly larger amount of enzyme than that needed for the formation of tastiness turns out rather to give a bad taste. On the other hand a great excess of the amount of Rhizopus mold protease did not change the tastiness produced there. Some analytical experiments on meat digests were undertaken to clarify such difference in the effect on meat according to the kind of proteolytic enzyme, and the implication of the results was discussed.
\end{abstract}

パパインなど，ある種蛋白質分解酵素は生肉の軟化な らびに旨味生成に有効であることはかなり古くから知ら れり，また実際に応用されている。またその際に起こる 肉の変化についてす組織解剖学的研究がある程度なされ ている2)。著者らは硬質生牛肉も一般調理用に仕向ける 方法を見出すことを目的として，種々蛋白分解酵素の硬 質肉におよほす影響を試験してきた。さきに, Papaiya latex を応用した米国製 meat tenderizer とわが国 で多量に生産されている枯草菌の中性 Protease ${ }^{3)}$ p Rhizopus 属系状菌 ${ }^{4}$ の Protease とを比較したところ 軟化力および旨味生成力は Rhizopus 属がPapain酵素 に劣らぬ優秀なるのであることを知りこれについて報 告した5)。

その後 Rhizopus 属系状菌の生産する Protease が優 秀であるのは，作用最適 $\mathrm{pH}$ が酸性側の Protease が一 般に旨味生成に好都合なのか, それとも系状菌 Protease の分解様式か Papain に近似しているためなのかど5 かを確かめるため，作用最適 $\mathrm{pH}$ の異なる酵素すなわち 著者らが従来供試して来た放線菌, 枯草菌及び Asper- gillus 属糸状菌ならびに植物 Protease や最近新たに入 手した種々の酵素剤のうち硬質牛肉にたいして有効なも のを, まず選別し, 次いで供試酵素を牛肉の $\mathrm{pH}$ と同じ 5.8 でカゼインに作用させ，Folin 法 $^{6)}$ の変法で酵素力 を比較し，それを尺度として生牛肉の軟化度，旨味生成 の有無, その程度を官能試験すると共に肉の分解度を種 ヶ方法で検討した。これら結果について報告する。

\section{実験方法および材料}

\section{1. 供試酵素剤の酵素活性度の比較}

市販牛肉は個体差ならびに部位差があるため基質とし て Caseinを用いた。Casein 溶液は牛肉のpHにあわ せて 5.8 とし，それに酵素を $20^{\circ} \mathrm{C} て ゙ 10$ 分間作用させた 後三塩化酢酸可溶性になった Folin 試薬呈色性アミノ 酸, ペプチッドをチロシン相当量として測定した。〔第 1 表(その 1 )(その 2 ) 参照つ。その条件でチロシン10 r を生ずる場合を酵素力 1 unit とし, 醉素剤相互の活性 度を比較した。その結果は第 2 表の通りであった。 
第 1 表 （その $1 ）$ カゼイン溶液の調慗

$$
\begin{aligned}
& \text { カゼイン } 1.2 \mathrm{~g} \\
& 1.2 \mathrm{M} \text { 尿素液 } \quad 30 \mathrm{ml} \\
& \leftarrow\{0.3 \mathrm{M} \text { 酶酸ソーダ液 } 30 \mathrm{ml} \\
& 0.3 \mathrm{M} \text { 第二燐酸ソーダ液 } 30 \mathrm{ml} \\
& \leftarrow \text { Conc. } \mathrm{HCl} \text { (溶解比必要な最少量) }
\end{aligned}
$$

pH 5.8 カゼイン溶液

世蒸溜水を加えて $100 \mathrm{ml}$ とする

$1.2 \%, \mathrm{pH} 5.8$ カゼイン溶液

（その 2 ）醅素力の測定

$1.2 \%$ ガイン溶液(pH5.8) $5 \mathrm{ml}+$ 水 $0.5 \mathrm{ml}$

予め $20^{\circ} \mathrm{C}$ に10分間以上インキュベート

世醉素液 $0.5 \mathrm{ml}$ 添加

$\leftarrow 10$ 分後 $0.4 \mathrm{M}$ TCA $5 \mathrm{ml}$ を添加

$20^{\circ} \mathrm{C}$ に30分間放置後汇過

\begin{tabular}{|c|c|c|}
\hline 酔 素 荗 （起 源） & 酵素力 & \begin{tabular}{|c|c} 
備用考 \\
$\mathrm{pH}$
\end{tabular} \\
\hline Papain(精㡀) cysteine で活性化 & u nits & $5 \sim 7$ \\
\hline Bromelain & 24 & $3.7 \sim 3.9$ \\
\hline Ficin & 27 & $4 \sim 9$ \\
\hline Aspergillus saitoi Protease & 3 & $2.5 \sim 3.0$ \\
\hline Rhizopus niveus Protease & 9 & $3 \sim 4$ \\
\hline Rhizopus chinensis Protease & 3 & 4 \\
\hline $\begin{array}{l}\text { Streptomyces griseus Protease. } \\
\text { (Pronase) }\end{array}$ & 17 & 7 \\
\hline $\begin{array}{l}\text { Bacillus subtilis alkaline } \\
\quad \text { Protease (Nagarse) }\end{array}$ & 6 & 10 \\
\hline
\end{tabular}

沪液 $2 \mathrm{ml}$ を分取

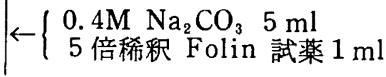

発色液

$\left\{\begin{array}{l}37^{\circ} \mathrm{C}, \quad 30 \text { 分後 } 1 \mathrm{~cm} \text { 層のキュベットを用い } 660 \\ \mathrm{~m} \mu \text { にて測定。加熱酵素を用い同㥞に操作して } \\ \text { 得た液をブランクとした。 }\end{array}\right.$

第 2 表 供試醉素郕の醉素力

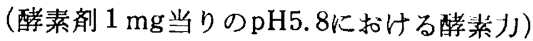

供試生牛肉

通称（京都）カケおよびマクラといわれる部分はイチ : (aitchbone) の5ら側で，すねに近い部分をいい， 剖学的 ${ }^{7}$ には腓側広筋, 内転筋, 半膜様筋などからな , 外観, 味ともに Round Steak ${ }^{8}$ や Roast として :まれるが，しかし一般に硬肉で牛の種類によっててはそ が甚だしい。実験には特にこの硬いカケ肉を用いた。
（京都三島亭より購入：第 1 図参照）

第 1 図

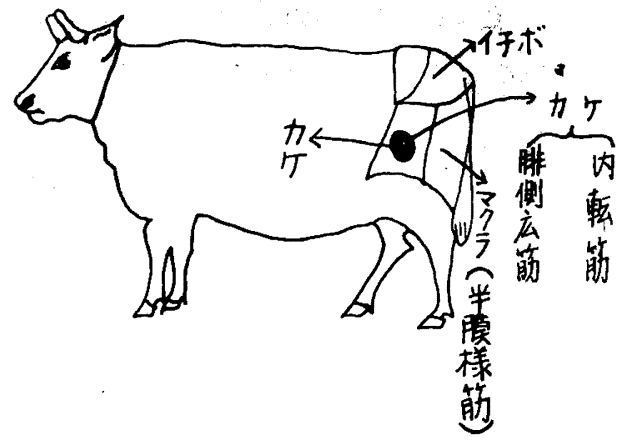

実 験 結 果

\section{1. 醉素剤の種類とその使用最適量}

前回と同様, 生肉を筋紻維に直角に約 $1.5 \mathrm{~cm}$ 巾に切断 し，後各切片の両端を切り落しながらだいたい四角で50 $\mathrm{g}$ 大の肉を用意し；それをホークでまんべんなくさした 後それに食塩 $0.4 \mathrm{~g}$ ，胡椒 $0.02 \mathrm{~g}$, 片栗粉 $5 \mathrm{~g}$ お よび䣼素

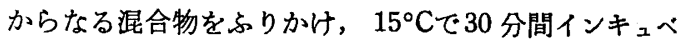
ートしたのち, サラダオイルをしいたフライパンで一定 条件下て焼いた。これについて Bradly9) の解析法を適 用しながら，やわらかさ，おいしさを比較した。なお， パネルが比較的熟練してきたので，おいしさ（旨味）と 適度のやわらかさの総合点を提出させた。第 2 図は12名 の熟練パネルによって採点された平均値を示したもので その順位は試験した酵蜏の中 Rhizopus. 属 Protease が最もよく Bacillus subtilis alkaline Protease, Bromelainはこれにつぎ, Pronase, Ficin はかなり 劣った。

なお，それぞれの酵素剤についてその使用量との関係

第 2 図各酵素倣に上る旨味生成の比較図

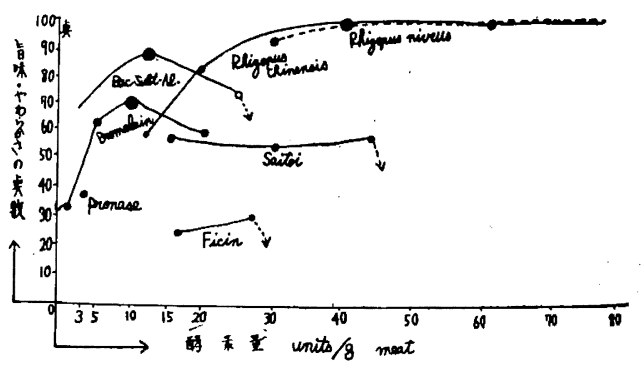

をみると，肉 $1 \mathrm{~g}$ 当りの酵素使用最適量は酵素活性で， Rhizopus niveus では40から80u, Bacillus subtilis alkalineでは12uであるが24uは却って劣り Bromelain は10u が最高でこの場合も酵索使用量が增すとかえって 悪結果になった。 


\section{2. 醉素処理肉の化学的検討}

官能検査によって醉素の生牛肉に対する叒劣をみるこ とはなお問題があると思われるが, 少なくも著者らの試 した酵素偊の中では Rhizopus 属系状菌の Protease が前報と同様㧊いしかったが，枯草菌のアルカリProtease がこれに次いで好まれる旨味を与えたことは注目 すべきことである。枯草菌中性 Protease は良結果を与 えなかった。植物酵索では Bromelain が良かったか， 枯草菌アルカリProtease よりは劣った。そこでこれら 三者についてそれぞれ生牛肉, 腓側広筋, 内転筋に作用 させ，その場合の蛋白分解の様相を検することにした。 すなわち第 3 表にしたがい測定した。

第3表 水溶性総N, アミノN, アンモニア $\mathrm{N}$ および TCA 可溶総 $\mathrm{N}$ 測定法

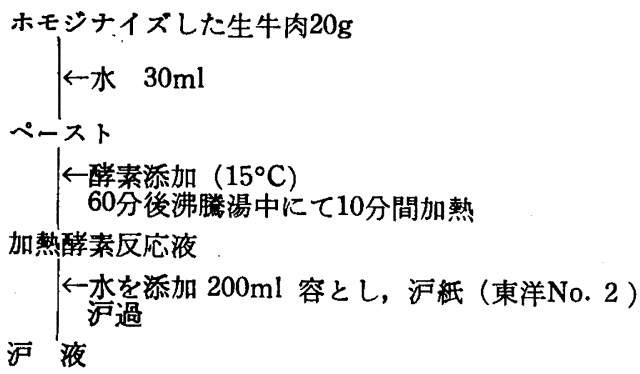

沪 液

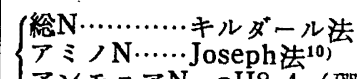

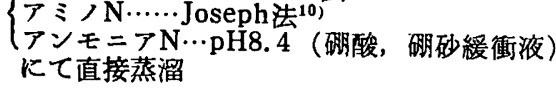

一部に等量の $1.2 \mathrm{M} \mathrm{TCA}, 37^{\circ} \mathrm{C} 30$ 分後沪過

TCA 可溶液

総N…………...ルダール法

醉素処理によって生成あるいは增加した水溶性の総窒 素, アミノ窒素, アンモニア窒素㧊よび TCA 可溶性の 総窒素を测定した。なお, 醅素は前記味覚試験ての最適 量ならびにその倍量を使用した。その結果は第 4 表の通 りで, 旨味の生成は蛋白の水溶性化, あるいは TCA 可 溶性化, アミノ基の增加などとは直接比例しない。どち らかといえば適度の分解の際に旨味は生成されるといい 得るにすきない。すなわち Rhizopus niveus はある程 度多くの䤃㝜が必要であるが枯草菌アルカリ Protease, Bromelainいずれの場合す少ない醉素量を用いた 時飞旨味が生成されている。そして Rhizopus niveus では水溶性Nが $6 \mathrm{mg}$ のきも $7.9 \mathrm{mg}$ のときも旨味の優 劣は殆んどないが，枯草菌アルカリ Protease は13mg Nでは旨味は少なくなるが9.8mg位ではかなりの旨味を 呈したからである。

これらのことから, Protease が適度に反応してある種 Peptide が生成された際に旨味が生じ，醭反応がそれ
以上進行すると，その旨味 Peptide が分解され旨味を 少なくするすのと考学られる。るちろんそれらの進行過 程ならびに生成旨味 Peptide の種類は Proteaseの種類 すなわち特異性によって異なると思われる。

第 4 表 酵素を作用させた場合の生肉の変化

\begin{tabular}{|c|c|c|c|c|}
\hline \multirow{3}{*}{$\begin{array}{l}\text { 消化に使った酵素と } \\
\text { その量 }\end{array}$} & \multicolumn{4}{|c|}{ 生肉 $1 \mathrm{~g}$ より生じた } \\
\hline & 水 & 溶 & 性 & $\begin{array}{l}\text { TCA } \\
\text { 可溶性 }\end{array}$ \\
\hline & $\begin{array}{l}\text { 総 } N \\
(\mathrm{mg})\end{array}$ & $\begin{array}{c}\mathrm{NH}_{2}-\mathrm{N} \\
(\mathrm{mg})\end{array}$ & $\begin{array}{l}\mathrm{NH}_{3} \cdot \mathrm{N} \\
(\mathrm{mg})\end{array}$ & $\begin{array}{l}\begin{array}{l}\text { 総N } \\
(\mathrm{mg})\end{array} \\
\end{array}$ \\
\hline 無処理（対照） & 4. 32 & 0.61 & - & 3.78 \\
\hline $\begin{array}{lr}\text { Rhizopus niveus pro- } \\
\text { tease } & 40 \mathrm{u} / \mathrm{g} \text { meat }\end{array}$ & 6.07 & 3.03 & 0.459 & 5.40 \\
\hline $\begin{array}{l}\text { Rhizopus niveus pro- } \\
\text { tease } \quad 80 \mathrm{u} / \mathrm{g} \text { meat }\end{array}$ & 7.97 & 4.50 & 0.675 & 6.61 \\
\hline $\begin{array}{l}\text { Bac. subtilis alkaline } \\
\text { protease } 12 \mathrm{u} / \mathrm{g} \text { meat }\end{array}$ & 9.72 & 4.00 & 0.405 & 8.10 \\
\hline 同上 $24 \mathrm{u} / \mathrm{g}$ meat & 13.51 & 5.39 & 0.675 & 10.94 \\
\hline Bromelain $10 \mathrm{u} / \mathrm{g}$ meat & 9.72 & 0.99 & 0.054 & 7.02 \\
\hline 同上 $20 \mathrm{u} / \mathrm{g}$ meat & 10.67 & 1.11 & 0.432 & 8. 78 \\
\hline
\end{tabular}

な打醭素処理はそのよ5に旨味を生ずるのみならず, 表などより明らかな如く，総蛋白Nの約 $1 / 5$ にも達する TCA 可溶 $\mathrm{N}$ を生じさせるなどのことから，消化吸収上 函めて有意義なことと思われる。

\section{総括ならびに考察}

硬質生牛肉カヶ（内転筇，腓側広筋）を軟化して一般 調理用にしむける方法を見出すことを目的として，種ヶ 蛋白分解酵素凨の硬質肉に及济す影響を試験した。

(1)官能試験の結果, 一般に軟化度, 旨味の点で Rhizopus属(niveus) 糸状菌の Protease (40 80u/g meat) が最子優れ，Bacillus subtilis alkaline Protease $(12 \mathrm{u} / \mathrm{g}$ meat), Bromelain (10u/g meat) がこれに次 ぎ Ficin(28u/g meat)は最も劣っていた。

(2)旨味生成に適当な酵素の量（酵素活性度にて比較） は酵素の種類によって異なった。すなわち旨味生成には Bacillus subtilis alkaline は比較的少量で足りるが, Rhizopus 属系状菌の場合はかなりの量を必要とした。 Bromelain など植物醳素の最適量は前者と同様であっ た。

(3)Rhizopus 属系状菌 Protease の場合は酵素の使用 量が相当過剩でも旨味が減退することはないが枯草菌ア ルカリProtease の場合は使用量が過剩になると著しく 旨味が減退した。 Bromelainなどの場合も枯草菌に似 た傾向があった。

(4)肉の軟化はだいたいに怙いて、いずれの酵素の場合 も醉甞の使用量と並行した。しかし旨味生成と肉の軟化 
との間には直接の並行関係はみられなかった。

(6)旨味生成と蛋白の水溶性化あるいは TCA 可溶化,

アミノ基の增加などとの間には㨁接比例性はみられずど ららかといえば，適度の分解の際に旨味が生成されると みなされるにすぎなかった。

(6)旨味が最高に達した場合の酵素による肉の分解度は 水溶性化したNとしてRhizopus 属系状菌 Protease で は約15\%, 枯草菌アルカリ Protease では22\%であった

終りに, 牛肉の組織解剖学的な御教示を給わった京大 教授上坂章次博士，贵重な酵素剤を御恵与いただいた大 阪市大の山本武彦博士, 長瀬産業の屋代光良氏および新 日本化学工業の市川和宏氏に嫨んで梁謝いたします。ま た，実験に協力を惜まれなかった藤井敬子，後藤明子， 後藤恵津子, 原田睦の諸姉に対して心より扰礼申し上げ ます。

\section{女 献}

1) Gottsehall, G. Y, et al. : Food Research. 7,373 $\sim 381$ (1942). H. Wang, et al. : Food Research $19,534 \sim 556$ (1954)

2) H.Wang \& Nehema Maynard : Division of Histology, American Meat Institute Foundation, Univ. of Chicago

3）福本, 山本, 市川; 日本芸芸化学誌32, 230 235(1958)

" " 32, 375 379(1958)

4) 山本, 福本, 市川, 鷹見; 日本莀芸化学大会要旨集(於 東京) (1959)

5）日本栄类・食糧学会総会（於大阪）にて発表 $(1960)$

6) 萩原文二; 酵素研究法 (赤倜四郎編) 第 2 巻 p. 242 (1956)

7) 上坂章次 : 和牛全書 (1952) 松井潔: 家畜比較解剖学 (1948)

8) 小林文子: 調理科学講座 4 応用調理学(下田吉人䀦) 8 (1962)

田中德三郎：西洋料理事典 p.305 (1962)

9) Bradley, Ferry: Biometrika., 39, 324 (1952)

10) 41,502 (1954)

10) Joseph R. Lpnes : Methods in Enzymology, Vol. 2, p. 468 471

(同志社女子大学)

\section{食㥍中のビタミンAおよび銅量と豚肝臓中のそれらの集積の関係， ならびにそれに対するガンマ線照射の影幽}

豚のビタミンAならびに銅の摄取量と，肝中のビタミ $\checkmark \mathrm{A}$, 銅量の関係を, 28 頭の 2 才豚ならびに 40 頭の幼 豕を用いて検討し，さらにその一部について，2才豚 1 頁あたり $350 r$ (レントゲン) の $r$ 線をCo-60 源より全. 身照射して，その影響をみた。

1.ビタミンAの補給は, 肝中の銅量を減少。

2. 銅の補給は, 肝中ビタミン $\mathrm{A}$ 量を增大。
3. $\gamma$ 線照射は，肝中の銅量を增大した。

Gamma Irradiation and Interrelation of Dietary vitamin A and Copper on Their Deposition in the Liver of Swine.

by R. L. Shirley, T.N. Meacham et al.,

J. Nutrition. 78, p. 454 (1962)

（久保） 